\title{
Entrepreneur Skills as an Effort to Increase Entrepreneurial Intentions through Entrepreneurship Education
}

\author{
Ahmad Jaenudin $^{1}$, Crisna Gabriel Octavilona ${ }^{1 *}$, Dwi Puji Astuti ${ }^{1}$ \\ ${ }^{1}$ Universitas Negeri Semarang \\ "Corresponding author.E-mail:crisnagabriel@student.unnes.ac.id
}

\begin{abstract}
Entrepreneurship education is the main key in improving entrepreneurship skills and entrepreneurial intentions for the younger generation. This study aims to determine whether there is an influence of the entrepreneurial skills variable on the entrepreneurial intentions of students and also to find out whether there is an influence of entrepreneurship education in strengthening or weakening the influence of entrepreneurial skills on entrepreneurial intentions. This study uses a quantitative approach, with statistical analysis using ex post facto quantitative data. Analysis of the data using Multiple Regression Analysis is used to find the functional relationship of two or more predictor variables with the criterion variables and MRA (Moderated Regression Analysis) to test and to analyze the effect of moderator variables. Collecting data using questionnaires and documentation. The results of this study indicate that the influence of entrepreneurial skills on students' entrepreneurial intentions can be seen in the value of the coefficient of determination (R2) of 0.331 or $33.1 \%$ while the rest is influenced by other variables. Furthermore, in the second regression equation involving the moderating variable, namely entrepreneurship education, it is known that entrepreneurship education can strengthen the influence of entrepreneurial skills on students' entrepreneurial intentions, it can be proven by looking at the value $(\mathrm{R})=0,576$ and the value of the coefficient of determination (R2) is 0,331 . In addition, there is a positive and significant interaction on the entrepreneurship education variable on the entrepreneurial skills and entrepreneurial intention variables.
\end{abstract}

Keywords: Entrepreneur Skills, Entrepreneurship Education, Entrepreneurial Intention

\section{INTRODUCTION}

Common problems that occur in a country are economic problems, namely unemployment and other social inequalities. Based on data from the Central Statistics Agency, in the August 2020 period, the number of unemployed people increased by 2.67 million people. Thus, the number of unemployed workers in Indonesia is 9.77 million people. The Covid-19 pandemic caused the open unemployment rate (TPT) which was successfully suppressed from 5.23 percent to an increase of 7.07 percent. The increase in TPT occurred due to an increase in the number of the workforce as of August 2020 by 2.36 million people to 138.22 million people. Although there was an increase in the labor force participation rate (TPAK) by 0.24 percentage points to 67.77 percent, there was a decrease in the number of working people.

Global conditions that occurred due to the Covid19 pandemic had a negative impact on the economy, causing difficulties in finding work. In addition to occurring in society in general, unemployment also occurs in college graduates or vocational high schools. Factors affecting unemployment are the high number of job seekers among these graduates as a result of the mental thinking and mindset of students to become employees in both the private and public sectors [1]. College graduates, both diplomas and bachelors, should be able to get jobs or even open their own jobs. For this reason, efforts are 
needed so that educated human resources can have the skills and expertise needed by the dynamics of the world of work, so that concerns about an increase in the number of educated unemployed can be suppressed [2]. Efforts that can be made to equip university graduates to have skills and competencies are to increase students' entrepreneurial intentions.

From the previous few years, entrepreneurship has become a national priority for various governments [3]. It is associated with increased innovation, increased productivity, job prospects and economic benefits [4], [5]. Thus, it is important to investigate the factors that might influence entrepreneurial intention (IE) in a robust theoretical model to develop and implement effective policies [6]. Several factors that can influence students' entrepreneurial intentions, especially in tertiary institutions, are entrepreneurship education, entrepreneurship skills, and attitudes towards entrepreneurship. Entrepreneurship in the context of education does not only focus on encouraging students to start businesses but also making students more creative, opportunity-oriented, proactive and innovative. Entrepreneurship education seeks to train students' abilities and willingness to create value for others. This is the essence of entrepreneurship and is also a competency that must be possessed by all students, regardless of career choice [7].

Skill development is something that needs to be done in entrepreneurship and becomes a challenge for the younger generation along with technological developments [8]. Entrepreneurial skills can enhance the ability of entrepreneurs by encouraging one to take risks, identify practical business methods and prepare to make all available opportunities [9]. In addition to entrepreneurial skills, there is an attitude towards entrepreneurship which is a factor in increasing students' entrepreneurial intentions. Attitudes towards entrepreneurship are emphasized as positive or negative personal judgments about being an entrepreneur choice of an entrepreneur or working in an organization [10]. Entrepreneurial attitude includes aspects that help individuals to take action including taking responsibility for their own learning, career and life [11], [12]. see someone who shows a positive attitude towards entrepreneurship, Have a greater chance of becoming an entrepreneur and believe that entrepreneurship is not only for survival but also a way to achieve self-actualization [13].

In addition to the factors described above, this study attempts to examine the entrepreneurial education variable as a factor that can positively or negatively affect students' entrepreneurial intentions. Every individual must be instilled with confidence and self-confidence to develop his ability to achieve certain goals. Students can start their learning activities with confidence and develop self-study strategies to achieve better goals [14]. The development of trust and confidence to achieve certain goals must receive encouragement and support from universities so that students can develop an independent-oriented interest in entrepreneurship [15].

This study aims to determine the mastery of entrepreneurial skills and attitudes can be a driving force in increasing students' entrepreneurial intentions through entrepreneurship education. This study uses the latest data with samples that match the criteria for research needs. In addition, this research has a contribution to the following research in order to increase the entrepreneurial intention of students as one of the provisions for the younger generation to contribute to increasing economic growth and creating jobs in the future.

\section{RESEARCH METHODS}

This study uses a quantitative approach, because the data are in the form of numbers and are analyzed based on statistical analysis using ex post facto quantitative data. Analysis of the data using Multiple Regression Analysis is used to find the functional relationship of two or more predictor variables with the criterion variables and MRA (Moderated Regression Analysis) to test and to analyze the effect of moderator variables. Moderated Regression Analysis (MRA) is used to identify the influence of the moderator variable as well as the type of moderator variable. Based on its relationship with the dependent variable $(\mathrm{Y})$, the moderator variable is divided into three types, namely the homologizer variable, the pseudo moderator variable (quasi moderator), and the original moderator variable (pure moderator).

The population in this study were Economic Education Students Class of 2018 totaling 350 students spread over 3 Study Programs in the Department of Economics Education, namely: Accounting Education, Cooperative Education and Office Administration Education. The sampling technique is incidental sampling, which is a technique for determining respondents based on the number of samples by chance, that is, anyone who coincidentally/incidentally meets with the researcher can be used as a sample, with consideration that if it is deemed that the person who happened to be met is suitable as a data source. 


\section{RESULTS AND DISCUSSION}

This study focuses on strengthening entrepreneurial intentions which are influenced by entrepreneurial skills through entrepreneurship education. The object of this research involves students who are already and have attended entrepreneurship courses at the Department of Economics Education, State University of Semarang. Data collection is done by using a questionnaire or questionnaire. To find out whether each variable has an influence or is influenced, data analysis is carried out using a simple regression test and a moderating variable analysis test to find out whether the moderating variable has a strengthening or weakening effect on other variables. There are criteria used in decision making that refer to the level of $=0.05$. $\mathrm{H} 0$ is rejected if the significance of

probability $(\mathrm{sig})<\alpha(0,05)$ or $\mathrm{t}$-count $>$ ttable, which means that there is an influence between the two variables and if the probability significance level $(\mathrm{sig})>(0.05)$ or tcount < table, then H0 is accepted, which means that there is no effect between the two variables. Based on the simple regression statistical test, the test results can be seen as follows.

Is there an influence of entrepreneurial skills on entrepreneurial intentions?

Table 1. Output Model Summary

\begin{tabular}{|c|c|c|c|c|}
\hline \multicolumn{4}{|c|}{ Model Summary } \\
\hline Model & $\mathrm{R}$ & R Square & Adjusted R Square & Std. Error of the Estimate \\
\hline 1 &, $576 \mathrm{a}$ &, 331 &, 325 &, 902 \\
\hline
\end{tabular}

Based on table 1, it can be explained that the value of the correlation coefficient or value $(R)=0.576$, which indicates that there is a relationship between the entrepreneurial skill variable $(\mathrm{X})$ and the student's entrepreneurial intention $(\mathrm{Y})$. this is also indicated by the value of the coefficient of determination (R2), which is 0.331 , which means that the magnitude of the influence of the entrepreneurial skill variable is $33 \%$ while the remaining $67 \%$ is influenced by other variables besides the variables studied.

Table 2. Output Coefficients

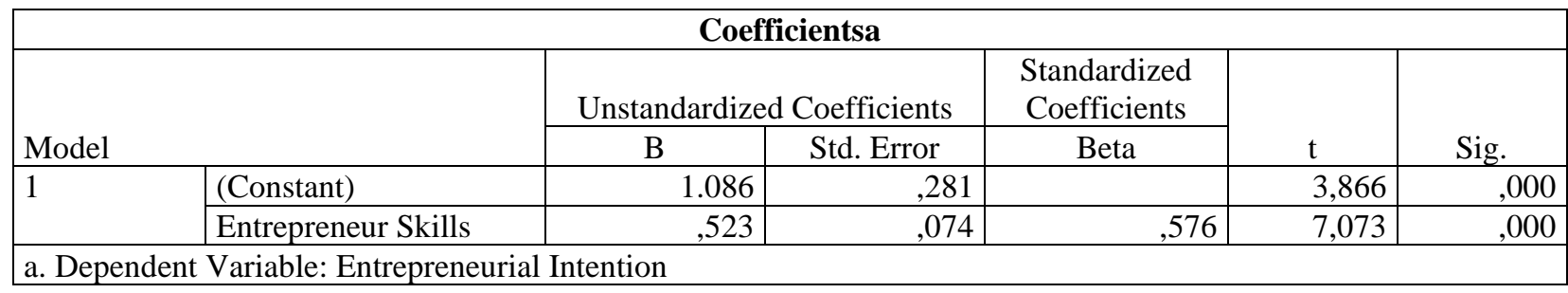

Based on table 3, it is known that the value of the entrepreneur skills regression coefficient is 0.532 with the significance value of the regression test is 0.000 $<0.05$ and the tcount is $2,906>$ ttable 1,983 , which means that according to the test criteria, it is explained that $\mathrm{H} 0$ is rejected. This shows that there is a positive and significant influence between entrepreneurial skills on entrepreneurial intentions.

The first regression equation aims to determine whether there is an influence between the entrepreneurial skills variable on the entrepreneurial intention variable. The results of data analysis show that the entrepreneurial skills variable has an effect on the entrepreneurial intention variable which can be seen in the value of the coefficient of determination (R2) of 0.331 or $33.1 \%$ while the rest is influenced by other variables. Entrepreneurship skills are the ability to use reason, thoughts, ideas and creativity to change and produce something of value, [16]. Entrepreneurship skills are a person's ability to be skilled and have creativity in entrepreneurship. There are 4 dimensions of entrepreneurial skills, namely technical skills, managerial skills, entrepreneurship skills and personal maturity skills, [17]. As is the case with research conducted by [18] revealed that there are four skills as the key to starting their own business namely risk taking, critical thinking, problem solving and innovation.

Thus, entrepreneurial skills include creativity, innovation and risk taking. Creativity refers to providing different and innovative approaches to new problems [19]. These entrepreneurial skills are also considered necessary for the community to have an independent and sustainable life and to contribute to economic and social development as well as to increase competitiveness [20]. Entrepreneurial skills can be obtained through training, workshops or formal education available in higher education. With entrepreneurship skills, a person will be increasingly 
motivated to have entrepreneurial intentions and do entrepreneurship.
Is there an effect of entrepreneurship education in strengthening entrepreneurial skills on entrepreneurial intentions?

Table 3. Output Model Summary Moderation

\begin{tabular}{|l|l|l|r|r|}
\hline \multicolumn{5}{|c|}{ Model Summary } \\
\hline Model & $\mathrm{R}$ & R Square & Adjusted R Square & Std. Error of the Estimate \\
\hline 1 &, $718 \mathrm{a}$ & \multicolumn{2}{|c|}{, 515} &, 500 \\
\hline
\end{tabular}

Based on table 4, it can be explained that the value of the correlation coefficient or value $(\mathrm{R})=0.718$, and the value of the coefficient of determination (R2) is 0.515 , after there is a moderating variable, namely Entrepreneurship Education in the second regression equation, it shows an increase compared to the first regression equation, a sign of the moderating variable, namely value $(\mathrm{R})=0.576$ and the value of the coefficient of determination (R2) is 0.331 . Thus, it can be concluded that the existence of a moderating variable, namely entrepreneurship education, can increase or strengthen the entrepreneurial skills variable on entrepreneurial intentions. This is also evidenced by the significant interaction between the entrepreneurial skills variable and the Entrepreneurial Education variable in strengthening the entrepreneurial intention variable.

Table 4. Output Coefficients

\begin{tabular}{|c|c|c|c|c|c|c|}
\hline \multicolumn{7}{|c|}{ Coefficientsa } \\
\hline \multirow{2}{*}{\multicolumn{2}{|c|}{ Model }} & \multicolumn{2}{|c|}{ Unstandardized Coefficients } & \multirow{2}{*}{$\begin{array}{c}\text { Standardized } \\
\text { Coefficients } \\
\text { Beta }\end{array}$} & \multirow[b]{2}{*}{$\mathrm{t}$} & \multirow[b]{2}{*}{ Sig. } \\
\hline & & $\mathrm{B}$ & Std. Error & & & \\
\hline \multirow[t]{4}{*}{1} & (Constant) & 2,185 &, 727 & & 3,003 &, 003 \\
\hline & Entrepreneur Skills &,- 140 & ,194 &,- 154 &,- 719 & ,474 \\
\hline & Entrepreneurship Education &,- 250 & ,226 &,- 251 & -1.108 & ,271 \\
\hline & $\begin{array}{l}\text { Entrepreneur } \\
\text { Skills*Entrepreneurship } \\
\text { Education }\end{array}$ &, 171 & 0.057 & 1.035 & 3,014 & ,003 \\
\hline
\end{tabular}

Based on table 4 , it shows that the significance value is 0.003 which means it is smaller than 0.05 and tcount $3.014>1.983$ so it can be concluded that there is an interaction between the entrepreneur skills variable and the entrepreneurial education variable in strengthening the entrepreneurial intention variable.

The second regression equation uses moderating regression because it involves a moderating variable, namely entrepreneurship education to determine whether the entrepreneurial education variable can strengthen or weaken the influence of the entrepreneurial skills variable on the entrepreneurial intention variable. Based on the results of data analysis shows that the entrepreneurial education variable can strengthen the influence of entrepreneurial skills on entrepreneurial intentions as evidenced by the value of the determinant coefficient (R2) of 0.515 , an increase from the first determinant coefficient (R2) of 0.331 . In addition, the entrepreneurship education variable also has a positive and significant interaction with the entrepreneurial skill and entrepreneurial intention variables, which can be proven by the coefficient value of 0.171 and the significance value of $0.003>0.05$.

In line with research conducted by [21] which states that entrepreneurship education has a very important role in providing skills for an entrepreneur in running his business as a daily necessity. Furthermore, similar research was also carried out by [22] which suggests that respondents' motivation has a positive effect on participation in entrepreneurship education programs and company creation. Second, participation in these programs positively influences an individual's entrepreneurial orientation and entrepreneurial skills. Furthermore, research conducted by [23] which shows that there is a statistically significant relationship between management student entrepreneurship education, attitudes towards entrepreneurship and entrepreneurial intentions. Entrepreneurship education has a relatively large influence on students' entrepreneurial intentions [24]. Entrepreneurship education has a positive impact on stimulating students' entrepreneurial intentions [25]. 
Entrepreneurship education is considered to be one of the most innovative and influential forces that determine the health of any country's competitive economy, [26]. Nurturing entrepreneurial skills and intentions among youth is at the core of the socioeconomic development agenda of countries around the world [27]. Entrepreneurship, as a promoter of economic activity, has gained wide popularity since its inception due to its considerable impact on the economic development of a particular region or country, [28], [29]. Thus the importance of entrepreneurship education and increasing entrepreneurial intentions as an effort to create new entrepreneurs. The role of universities in providing entrepreneurship education for students is the main key to preparing young people who are ready to compete and are able to contribute in creating new jobs.

\section{CONCLUSION}

This study aims to determine whether there is an influence of the entrepreneurial skills variable on the entrepreneurial intentions of students and also to find out whether there is an influence of entrepreneurship education in strengthening or weakening the influence of entrepreneurial skills on entrepreneurial intentions. Based on the results of data analysis in the first regression equation, it shows that there is an influence of entrepreneurial skills on students' entrepreneurial intentions, which can be seen in the coefficient of determination (R2) of 0.331 or $33.1 \%$ while the rest is influenced by other variables. Furthermore, in the second regression equation involving a moderating variable, namely entrepreneurship education, it is known that entrepreneurship education can strengthen the influence of entrepreneurial skills on students' entrepreneurial intentions, can be proven by looking at the value $(R)=0.576$ and the coefficient of determination (R2) is 0.331. In addition, there is a positive and significant interaction on the entrepreneurship education variable on the entrepreneurial skills and entrepreneurial intention variables. Thus, the importance of entrepreneurship education in improving entrepreneurial skills and entrepreneurial intentions of students. The participation of universities is highly expected to create a golden generation that has enthusiasm, high competitiveness and has entrepreneurial skills as a provision to compete in global competition. the importance of entrepreneurship education in improving students' entrepreneurial skills and entrepreneurial intentions. The participation of universities is highly expected to create a golden generation that has enthusiasm, high competitiveness and has entrepreneurial skills as a provision to compete in global competition. the importance of entrepreneurship education in improving students' entrepreneurial skills and entrepreneurial intentions. The participation of universities is highly expected to create a golden generation that has enthusiasm, high competitiveness and has entrepreneurial skills as a provision to compete in global competition.

\section{ACKNOWLEDGMENTS}

We would like to thank the Faculty of Economics, State University of Semarang for facilitating research so that this research can run smoothly. We also thank the respondents who have taken the time to contribute to this research. as well as the editorial team of article publishers who have facilitated the publication of the articles that we have compiled

\section{REFERENCES}

[1] A. M. Mahendra, E. T. Djatmika, and A. Hermawan, "The Effect of Entrepreneurship Education on Entrepreneurial Intention Mediated by Motivation and Attitude among Management Students, State University of Malang, Indonesia," Int. Educ. Stud., vol. 10, no. 9, 2017 p. 61, doi: 10.5539/ies.v10n9p61.

[2] S. Maryati, "Dinamika Pengangguran Terdidik: Tantangan Menuju Bonus Demografi Di Indonesia," Economica, vol. 3, no. 2, 2015 pp. 124-136, doi: 10.22202/economica.2015.v3.i2.249.

[3] A. Al Mamun, R. A. Muniady, M. A. H. Bin Ibrahim, and N. B. C. Nawi, "Effect of economic vulnerability on entrepreneurial competencies among Malaysian micro-entrepreneurs," Asia Pacific J. Innov. Entrep., vol. 12, no. 2, 2018, pp. 222-237, doi: 10.1108/apjie-03-2018-0013.

[4] W. W. Kirkley, "Cultivating entrepreneurial behaviour: entrepreneurship education in secondary schools," Asia Pacific J. Innov. Entrep., vol. 11, no. 1, 2017, pp. 17-37, doi: 10.1108/apjie-04-2017-018.

[5] C. Park, "A study on effect of entrepreneurship on entrepreneurial intention," Asia Pacific J. Innov. Entrep., vol. 11, no. 2, 2017, pp. 159-170, doi: 10.1108/apjie-08-2017-024.

[6] M. Farrukh, Y. Alzubi, I. A. Shahzad, A. Waheed, and N. Kanwal, "Entrepreneurial intentions," Asia Pacific J. Innov. Entrep., vol. 12, no. 3, 2018, pp. 399-414, doi: 10.1108/apjie-01-2018-0004.

[7] L. Aldianto, G. Anggadwita, and A. N. Umbara, "Entrepreneurship education program as value creation: Empirical findings of universities in Bandung, Indonesia," J. Sci. Technol. Policy 
Manag., vol. 9, no. 3, 2018, pp. 296-309, doi: 10.1108/JSTPM-03-2018-0024.

[8] N. Kunicina, I. Bilic, A. Zabasta, J. Caiko, and L. Ribickis, "Development of entrepreneurship skills for students creative thinking support in higher education," 2019 Int. Conf. Eng. Appl. ICEA 2019 - Proc., 2019, pp. 1-6, doi: 10.1109/CEAP.2019.8883450.

[9] M. Sousa, "Entrepreneurship Skills Development in Higher Education Courses for Teams Leaders," Adm. Sci., vol. 8, no. 2, 2018, p. 18, doi: 10.3390/admsci8020018.

[10] V. Vamvaka, C. Stoforos, T. Palaskas, and C. Botsaris, "Attitude toward entrepreneurship, perceived behavioral control, and entrepreneurial intention: dimensionality, structural relationships, and gender differences," J. Innov. Entrep., vol. 9, no. 1, 2020, doi: 10.1186/s13731-020-0112-0.

[11] H. Mopangga, "Faktor Determinan Minat Wirausaha Mahasiswa Fakultas Ekonomi dan Bisnis Universitas Negeri Gorontalo," Trikonomika, vol. 13, no. 1, 2014, p. 78, doi: 10.23969/trikonomika.v13i1.486.

[12] M. P. Ajiwibawani, . H., and W. T. Subroto, "The Effect of Achievement Motivation, Adversity Quotient, and Entrepreneurship Experience on Students Entrepreneurship Attitude," Int. J. Acad. Res. Bus. Soc. Sci., vol. 7, no. 9, 2017, pp. 441450, doi: 10.6007/ijarbss/v7-i9/3339.

[13] J. Yang, "The theory of planned behavior and prediction of entrepreneurial intention among Chinese undergraduates," Soc. Behav. Pers., vol. 41, no. 3, 2013, pp. 367-376, doi: 10.2224/sbp.2013.41.3.367.

[14] M. Yusuf, "The impact of self-efficacy, achievement motivation, and self-regulated learning strategies on students' academic achievement," Procedia - Soc. Behav. Sci., vol. 15, 2011, pp. 2623-2626, doi: 10.1016/j.sbspro.2011.04.158.

[15] L. Shi, X. Yao, and W. Wu, "Perceived university support, entrepreneurial self-efficacy, heterogeneous entrepreneurial intentions in entrepreneurship education: The moderating role of the Chinese sense of face," J. Entrep. Emerg. Econ., no. 0501, 2019, doi: 10.1108/JEEE-042019-0040.

[16] J. Sagir, H. Husnan, and Mulyadi, "Pengaruh Pemberian Mata Kuliah Pengembangan Kewirausahaan Terhadap Minat dan Keterampilan Berwirausaha Mahasiswa pada Fakultas Ekonomi Dan Bisnis Universitas Mataram," J. Magister Manaj. Unram, vol. 9, no.

$$
\text { 2, 2020, pp. 161-174. }
$$

[17] J. Chang and A. Rieple, "Assessing students' entrepreneurial skills development in live projects," J. Small Bus. Enterp. Dev., vol. 20, no. 1, 2013, pp. 225-241, doi: $10.1108 / 14626001311298501$.

[18] S. M. R. Reyad, A. Musleh Al-Sartawi, S. Badawi, and A. Hamdan, "Do entrepreneurial skills affect entrepreneurship attitudes in accounting education?," High. Educ. Ski. Work Learn., vol. 9, no. 4, 2019, pp. 739-757, doi: 10.1108/HESWBL-01-2019-0013.

[19] M. Portuguez Castro, C. R. Scheede, and M. G. Gómez Zermeño, "Entrepreneur profile and entrepreneurship skills: Expert's analysis in the Mexican entrepreneurial ecosystem," 2020 Int Conf. Technol. Entrep. - Virtual, ICTE-V 2020, vol. 2020-April, 2020, pp. 1-6, doi: 10.1109/ICTE-V50708.2020.9114372.

[20] L. M. Chew, L. S. Hoe, T. C. Kim, and L. W. Y. Kiaw, "Self-perceived entrepreneurship skills for undergraduates of private university in Malaysia," Am. J. Appl. Sci., vol. 13, no. 6, 2016, pp. 715725, doi: 10.3844/ajassp.2016.715.725.

[21] F. F. Almahry, A. Sarea, A. M. Hamdan, and M. M. S. Al Mubarak, "The Impact of Entrepreneurship Education on Entrepreneurs' Skills," no. February, 2019, pp. 183-197, doi: 10.4018/978-1-5225-9377-5.ch009.

[22] A. Galvão, C. Marques, and J. J. Ferreira, "The role of entrepreneurship education and training programmes in advancing entrepreneurial skills and new ventures," Eur. J. Train. Dev., vol. 44, no. 6-7, 2020, pp. 595-614, doi: 10.1108/EJTD10-2019-0174.

[23] O. Boubker, M. Arroud, and A. Ouajdouni, "Entrepreneurship education versus management students' entrepreneurial intentions. A PLS-SEM approach," Int. J. Manag. Educ., vol. 19, no. 1, 2021, p. 100450, doi 10.1016/j.ijme.2020.100450.

[24] H. Mei, C. H. Lee, and Y. Xiang, "Entrepreneurship education and students' entrepreneurial intention in higher education," Educ. Sci., vol. 10, no. 9, 2020, pp. 1-18, doi: 10.3390/educsci10090257.

[25] Z. A. Paray and S. Kumar, "Does entrepreneurship education influence entrepreneurial intention among students in HEI's?: The role of age, gender and degree background," J. Int. Educ. Bus., vol. 13, no. 1, 2020, pp. 55-72, doi: 10.1108/JIEB-02-20190009. 
[26] R. K. Jena, "Measuring the impact of business management Student's attitude towards entrepreneurship education on entrepreneurial intention: A case study," Comput. Human Behav., vol. 107, no. January, p. 106275, 2020, doi: 10.1016/j.chb.2020.106275.

[27] N. Aboobaker and R. D, "Human capital and entrepreneurial intentions: do entrepreneurship education and training provided by universities add value?," Horiz., vol. 28, no. 2, 2020, pp. 7383, doi: 10.1108/OTH-11-2019-0077.

[28] A. Hassan, I. Saleem, I. Anwar, and S. A. Hussain,
"Entrepreneurial intention of Indian university students: the role of opportunity recognition and entrepreneurship education," Educ. Train., vol. 62 , no. 7-8, 2020, pp. 843-861, doi: 10.1108/ET02-2020-0033.

[29] S. Karimi, H. J. A. Biemans, T. Lans, M. Chizari, and M. Mulder, "The Impact of Entrepreneurship Education: A Study of Iranian Students' Entrepreneurial Intentions and Opportunity Identification," J. Small Bus. Manag., vol. 54, no. 1, 2016, pp. 187-209, doi: 10.1111/jsbm.12137. 